\title{
Studies by Microelectrophoretic and Microscopic Techniques of the Sorption of Illite and Montmorillonite to Rhizobia
}

\author{
By K. C. MARSHALL \\ Department of Agricultural Science, University of Tasmania, \\ Hobart, Tasmania 7001, Australia \\ (Accepted for publication Io February I969)
}

\begin{abstract}
SUMMARY
Electrophoretic measurements indicated that with increasing concentrations of illite or montmorillonite the surfaces of bacteria became progressively enveloped by a layer of adsorbed clay. The amount of clay adsorbed per unit area of cell surface depended mainly on the surface ionogenic properties of the isolates of the Rhizobium species used. For any particular isolate, almost identical amounts of illite and montmorillonite were adsorbed per bacterium. Microscopic studies confirmed the presence of a clay envelope around the bacteria and provided some information on the mode of adsorption of the clays.
\end{abstract}

\section{INTRODUCTION}

Investigations of the electrophoretic mobility of bacteria in the presence of colloidal montmorillonite have indicated that sorption of the montmorillonite results in the formation of a clay envelope around the organisms (Lahav, I962; Marshall, I968a). More detailed information on the nature of bacterium/clay interactions has now been obtained by a comparison of the electrophoretic properties of bacteria + montmorillonite with those of bacteria + illite. The association of clays with bacteria has also been examined by fluoresence and electron microscopy.

\section{METHODS}

Organisms. The organisms used in electrophoretic studies were cultures of rootnodule bacteria with different ionogenic properties (Marshall, 1967). Rhizobium trifolii TAI and $R$. lupini UT I 2 possess simple acidic (carboxyl) surfaces, whilst $R$. trifolii SU297B and $R$. trifolii SU298D have acidic groups along with some basic (amino) groups. These particular organisms were chosen because one from each group $(R$. trifolii TAI and $R$. trifolii SU298D) exhibited an electrophoretic mobility greater than that of Na-illite particles, whilst the mobilities of the remaining cultures ( $R$. lupini UT I 2 and $R$. trifolii SU297 B) were considerably lower than that of the illite.

Rhizobium trifolii SU297 B was used for the electron microscope study of rhizobium/ clay interactions, but a culture of Bacillus subtilis was used for fluorescence microscopy since the larger bacilli facilitated observation and photography.

All Rhizobium trifolii isolates were grown on yeast + mannitol agar for 3 to 4 days at $28^{\circ} ; R$. lupini UT 12 was grown on the same medium at $28^{\circ}$ for 10 to 12 days; Bacillus subtilis was grown on nutrient agar at $37^{\circ}$ for $6 \mathrm{hr}$.

Clay preparation. Suspensions of homoionic Na-montmorillonite and Na-illite were 
prepared from Volclay bentonite (American Colloid Co., Skokie, Illinois) and Fithian illite (Wards Natural Science Establishment, Rochester, N.Y.), respectively, as described by Lahav (1962). The concentrated clay suspensions were stored under refrigeration and appropriate dilutions were prepared as required.

Determination of electrophoretic mobility. Bacterial suspensions were prepared as described by Marshall (1968a). The electrophoretic mobility of the rhizobia in the presence or absence of clays was measured as described previously (Marshall, 1967), except that organisms were timed over a distance of $69 \mu$ at the upper stationary level. Measurements were made with bacterial concentrations of about $10 \times 10^{6} \mathrm{rhizobia} / \mathrm{ml}$. in an $\mathrm{NaCl}$ solution of ionic strength 0.05 . More dilute rhizobial suspensions were used to determine 'limiting mobility' values (Marshall, I968a).

Surface area of rhizobia. The length and diameter of the rhizobia (plus capsules where present) were determined by measurement of negatively stained preparations with a calibrated filar micrometer. The surface areas were calculated by assuming the rhizobia to be cylinders with flat ends.

Fluorescence microscopy. Washed Bacillus subtilis organisms were suspended in a solution of $0.01 \%$ acridine orange in $0.1 \mathrm{M}$-phosphate buffer $\left(\mathrm{pH}_{5} .0\right)$ for $4 \mathrm{hr}$. The bacteria were then washed three times in phosphate buffer, and mixed with equal quantities of water or an aqueous suspension of Na-montmorillonite to give a final concentration of $100 \mu \mathrm{g}$. clay $/ \mathrm{ml}$. Wet and dry amounts of these preparations were examined under a Leitz Ortholux fluorescence microscope. The filters used were the I and $2 \mathrm{~mm}$. UG Ifilters, a BG 38 heat-absorbing filter, and a $\mathrm{K}_{430}$ barrier filter. Exposure time was $3 \mathrm{~min}$. with Kodachrome II film.

Electron microscopy. The samples were freeze-dried directly on collodion-carbon films on grids in order to avoid artifacts arising from surface tension effects during drying of the bacterium + clay suspensions on the grids (Kittrick, 1965). Any fluffy material on the grids after freeze-drying was carefully removed. Some specimens were shadowed with gold + palladium $(60 \%$ gold $+40 \%$ palladium $)$. All observations were made with an AEI EM6 electron microscope at $60 \mathrm{kV}$.

\section{RESULTS}

\section{Effects of clays on the electrophoretic mobility of rhizobia}

The four Rhizobium isolates exhibited quite different and characteristic mobilities in the absence of any clay, but they all responded in a similar manner to increasing concentrations of Na-montmorillonite (Fig. I A). The mobility of rhizobia of all cultures increased until they approximated that of the $\mathrm{N}$-montmorillonite, suggesting that the observed rhizobial mobility actually is a measure of the mobility of a Namontmorillonite envelope around each organism (Marshall, 1968a). Studies with Na-illite (Fig. I B) also provided convincing evidence for the existence of such a clay envelope. Where the characteristic mobility of an isolate was lower than that of illite, the observed mobility increased with increasing clay concentration, as found with montmorillonite. With rhizobia possessing characteristically high mobilities, the observed mobility decreased with increasing clay concentration to a value about that of illite. Thus, the curves in Fig. I B show very clearly that the rhizobial mobilities observed at high clay concentrations reflected the characteristic mobility of the clay adsorbed on the rhizobial surface. 
For each rhizobial isolate, the amount of clay adsorbed per rhizobium was determined by the 'limiting mobility' method of Nevo, De Vries \& Katchalsky ( 1955 ). Adsorption isotherms were obtained by plotting the amounts of illite or montmorillonite adsorbed per rhizobium at different mobilities, against the free or equilibrium concentrations of the respective clays (Fig. $2 \mathrm{~A}, \mathrm{~B}$ ). Inspection of these Langmuirtype adsorption isotherms revealed a range of degrees of saturation of clay adsorbed per rhizobium for the different cultures. The total amounts of either illite or mont-
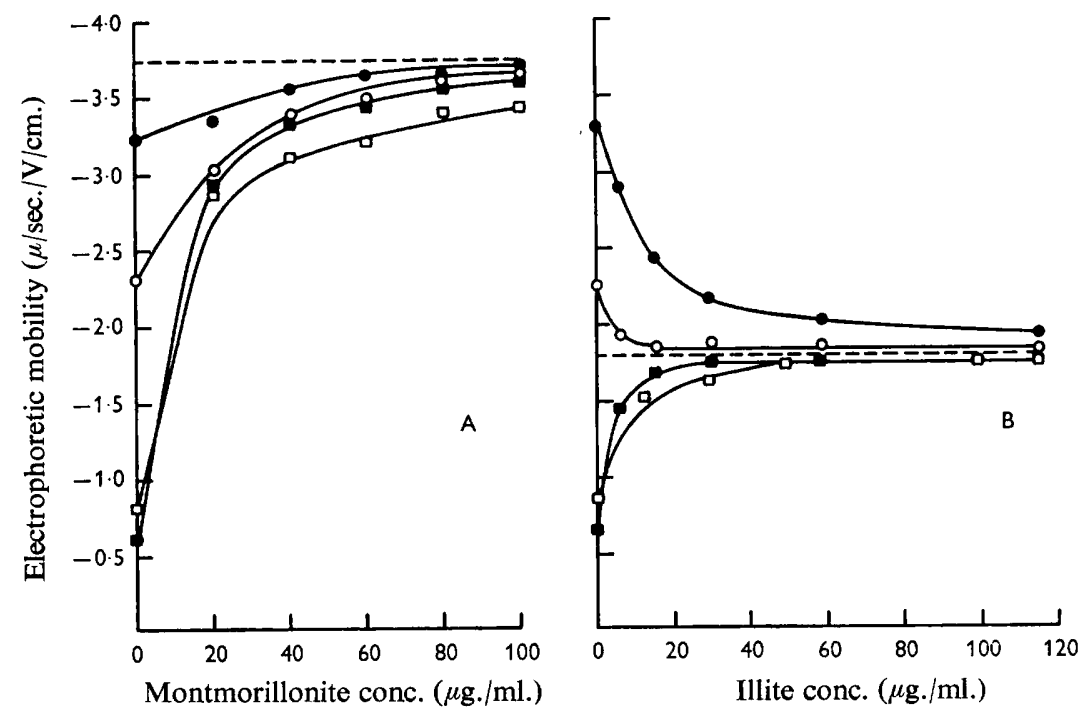

Fig. I. Changes in the observed electrophoretic mobility of rhizobia with increasing clay concentration. $-\longrightarrow$, Rhizobium trifolii su298D; $\bigcirc-\mathrm{O}, R$. trifolii TAI; $-\square, R$. lupini UT I2; $\square-\square, R$. trifolii SU297 в. A, broken line indicates mobility of Na-montmorillonite particles; B, broken line indicates mobility of Na-illite particles.
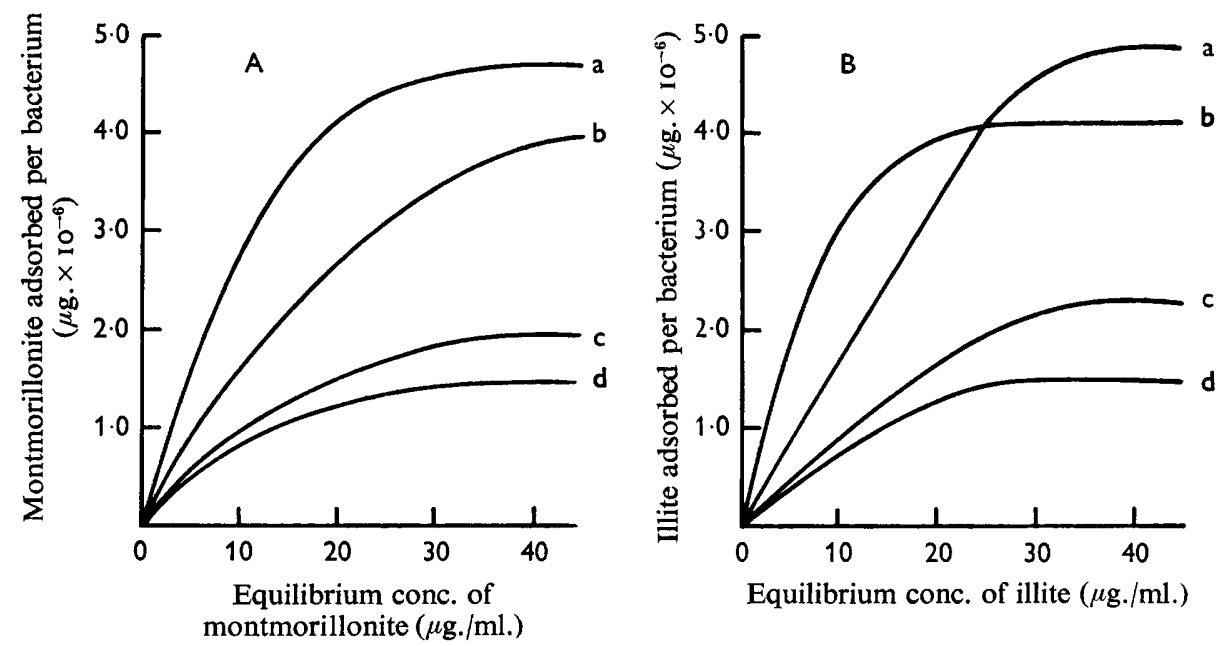

Fig. 2. Adsorption isotherms of A, Na-montmorillonite and B, Na-illite on: (a) Rhizobium lupini UT I2; (b) R. trifolii $\mathrm{TAI}$; (c) R. trifolii SU298D; (d) R. trifolii $\mathrm{SU} 297$ B. 
morillonite adsorbed per rhizobium for each individual isolate were remarkably similar (Table I). As found previously with adsorption of montmorillonite (Marshall, I968a), rhizobia with a simple carboxyl surface adsorbed about twice as much montmorillonite or illite per unit area of rhizobial surface as did rhizobia with a complex carboxyl + amino surface (Table $\mathrm{r}$ ).

Table I. Saturation levels of adsorbed Na-montmorillonite and Na-illite per bacterium and per unit area of bacterial surface on four isolates of Rhizobium

\begin{tabular}{|c|c|c|c|c|c|c|}
\hline \multirow[b]{2}{*}{ Organism } & \multirow{2}{*}{$\begin{array}{c}\text { Surface } \\
\text { ionogenic } \\
\text { groups }\end{array}$} & \multirow{2}{*}{$\begin{array}{c}\text { Surface } \\
\text { area of } \\
\text { bacteria } \\
\left(\mu^{2}\right)\end{array}$} & \multicolumn{2}{|c|}{ Montmorillonite adsorbed } & \multicolumn{2}{|c|}{ Illite adsorbed } \\
\hline & & & $(\mu \mathrm{g} . /$ rhizobium $)$ & $\left(\mu \mathrm{g} \cdot / \mu^{2}\right)$ & ( $\mu \mathrm{g} . /$ rhizobium) & $\left(\mu \mathrm{g} \cdot / \mu^{2}\right)$ \\
\hline R. trifolii TAI & Carboxyl & $6 \cdot 82$ & $3.98 \times 10^{-6}$ & $0.58 \times 10^{-6}$ & $4.10 \times 10^{-8}$ & $0.60 \times 10^{-6}$ \\
\hline R. lupini UTI 2 & Carboxyl & $9 \cdot 24$ & $4.70 \times 10^{-6}$ & $0.51 \times 10^{-6}$ & $4.90 \times 10^{-6}$ & $0.53 \times 10^{-6}$ \\
\hline $\begin{array}{l}\text { R. trifolii } \\
\text { SU297 B }\end{array}$ & $\begin{array}{l}\text { Carboxyl }+ \\
\text { amino }\end{array}$ & $5 \cdot 58$ & $\mathrm{I} \cdot 55 \times 10^{-6}$ & $0.28 \times 10^{-6}$ & $1.45 \times 10^{-6}$ & $0.26 \times 10^{-6}$ \\
\hline $\begin{array}{l}R . \text { trifolii } \\
\text { SU298D }\end{array}$ & $\begin{array}{l}\text { Carboxyl }+ \\
\text { amino }\end{array}$ & $8 \cdot 17$ & $2.03 \times 10^{-6}$ & $0.25 \times 10^{-6}$ & $2 \cdot 30 \times 10^{-6}$ & $0.28 \times 10^{-6}$ \\
\hline
\end{tabular}

Microscopic observation of bacterium-clay interaction

Because of the fine colloidal nature of the clays used it was not possible to observe directly by light microscopy an interaction between bacteria and the clays. An indirect demonstration of the presence of a clay coating around Bacillus subtilis organisms was achieved by observations under a fluorescence microscope of bacteria stained with acridine orange. The addition of a dilute suspension of $\mathrm{Na}$-montmorillonite to a suspension of stained bacilli markedly decreased the intensity of the fluorescent image of the bacillia (Pl. I, fig. I, 2). This result suggested that clay particles partially coated the bacterial surface and interfered with the production of the fluorescent image.

A more direct observation of the mode of adsorption of clays on rhizobia was obtained by electron microscopy. Unshadowed and shadowed preparations of rhizobia in the absence of clays are shown in Pl. I, fig. 3, 4. Unshadowed preparations of rhizobia + clay indicate that the Na-montmorillonite adsorbed around the rhizobia was much less electron-dense than the Na-illite ( $\mathrm{Pl}$. 2, fig. 5; Pl. 3, fig. 7), while shadowed preparations showed that this was a difference in the thickness of the individual clay particles (Pl. 2, fig. 6; Pl. 3, fig. 8). The electron micrographs show the distinct envelope of adsorbed clay around the rhizobia. There appeared to be more montmorillonite than illite adsorbed to each rhizobium, but each illite particle was very much thicker than the montmorillonite particle.

\section{DISCUSSION}

The suggestion that in suspensions of mixed clay + bacteria the outer surface of bacteria might become covered by adsorbed clay particles (Marshall, I968a) has been confirmed by the electrophoretic and microscopic observations reported in the present paper. Such a clay envelope may be of significance in modifying the microenvironment around individual micro-organisms in certain natural soils (Marshall, 1964, I968 $b$; Stotzky \& Rem, 1966). In addition to providing some indirect evidence 
for the existence of a clay envelope around the bacteria, the studies on fluorescently labelled Bacillus subtilis indicated that even minute amounts of clay $(100 \mu \mathrm{g} . / \mathrm{ml}$. of bacterial suspension) could interfere with the fluorescence image obtained with the u.v. microscope. This effect may explain the interference reported (Eren \& Pramer, I966; Schmidt, Bankole \& Bohlool, 1968) in the use of the fluorescently-labelled antibody technique for the detection of specific micro-organisms in soils with high clay contents.

A feature of the sorption studies was the remarkable similarity between the amounts of illite and montmorillonite adsorbed per rhizobium for any particular isolate. It appears that the nature of the ionogenic surface of the root-nodule Rhizobium organisms was the most important factor in determining the amount of illite or montmorillonite adsorbed per unit area of rhizobial surface. Broadly speaking, the amount of clay adsorbed seems to be independent of the net surface-charge density (as indicated by the characteristic electrophoretic mobilities) either of the rhizobia or of the illite and montmorillonite. As noted previously (Marshall, 1968a), however, there is some relationship within each group of Rhizobium isolates with similar surface ionogenic properties between the electrokinetic charge of the rhizobia and the amount of clay adsorbed per unit area.

An attempt was made by Marshall (1968a) to explain the effect of ionogenic properties of bacteria on adsorption of clay by a consideration of the orientation of individual clay platelets (crystals) at the bacterial surface. It is obvious from the present electron micrographs that both the montmorillonite and illite clays were in a flocculated condition. Consequently, it is not possible to consider the sorption process solely in terms of the orientation of individual clay crystals at the surface of the bacteria. However, these electron micrographs do reveal that most clay particles were adsorbed on to the rhizobial surface in an edge-to-face, rather than a face-to-face, manner. This observation may help to explain the similarity in the amounts of illite and montmorillonite adsorbed per rhizobium, since any positive charge on the edge of the different clays is likely to be similar even though the net surface-charge density of the clays is very different. It does appear from observations with the electron microscope that a greater number of montmorillonite particles were adsorbed per rhizobium than illite particles. It must be noted, however, that the illite particles are much thicker than those of the montmorillonite, and it is feasible that the weights of the clays adsorbed per rhizobium were similar as indicated by the electrophoretic studies.

To have conditions in electron microscopy comparable to those used in the electrophoretic studies, the bacterium + clay suspensions were freeze-dried on grids to avoid artifacts arising from surface tension effects during drying. In natural soil environments, however, the accumulation of clay particles at the surfaces of bacteria as a result of surface tension during drying of the soil may be a normal situation. Such conditions are of some practical significance in soils where certain clay types apparently protect root-nodule bacteria from the detrimental effects of desiccation and high temperatures (Marshall \& Roberts, I963; Marshall, 1964).

This work was supported by a grant from the Australian Research Grants Committee. The author is grateful to Miss Joanna Giblin for technical assistance and to Dr J. A. Beattie for helpful comments on this work. Thanks are due to Professor B. Johnson for permission to use the electron microscope and to $\mathrm{Mr} \mathrm{B}$. Dixon for the operation of the instrument and preparation of the electron micrographs. 


\section{REFERENCES}

ERen, J. \& Pramer, D. (I966). Application of immunofluorescent staining to studies of the ecology of soil micro-organisms. Soil Sci. ror, 39.

KitTrick, J. A. (1965). Electron microscope techniques. In Methods of Soil Analysis. Ed. by C. A. Black. Part I, p. 632. Madison: American Society of Agronomy Monograph No. 9.

LAHAv, N. (1962). Adsorption of sodium bentonite particles on Bacillus subtilis. Pl. Soil 17, I9I.

Marshall, K. C. (1964). Survival of root-nodule bacteria in dry soils exposed to high temperatures. Aust. J. agric. Res. 15, 273.

MARShall, K. C. (1967). Electrophoretic properties of fast- and slow-growing species of Rhizobium. Aust. J. biol. Sci. 20, 429.

Marshall, K. C. (1968a). Interaction between colloidal montmorillonite and cells of Rhizobium species with different ionogenic surfaces. Biochim. biophys. Acta 156, I 79.

MARShaLL, K. C. (1968 b). The nature of bacterium-clay interactions and its significance in survival of Rhizobium under arid conditions. Trans. 9th Intern. Congr. Soil Sci. 3, 275.

Marshall, K. C. \& RoberTs, F. J. (1963). Influence of fine particle materials on survival of Rhizobium trifolii in sandy soil. Nature, Lond. $198,410$.

Nevo, A., De Vries, A. \& Katchalsky, A. (1955). Interaction of basic polyamino acids with the red blood cell. I. Combination of polylysine with single cells. Biochim. biophys. Acta 17, 536.

SChmidt, E. L., Bankole, R. O. \& BoHLOOL, B. B. (1968). Fluorescent-antibody approach to study of rhizobia in soil. J. Bact. $95,1987$.

STotzky, G. \& Rem, L. T. (I966). Influence of clay minerals on micro-organisms. I. Montmorillonite and kaolinite on bacteria. Can. J. Microbiol. 12, 547.

\section{EXPLANATION OF PLATES}

\section{Plate I}

Fig. I. Bacillus subtilis stained with acridine orange. Air-dried preparation, ultraviolet irradiation; $\times 1000$.

Fig. 2. B. subtilis stained with acridine orange. Montmorillonite ( $100 \mu \mathrm{g} . / \mathrm{ml}$.) added. Air-dried preparation; u.v. irradiation; $\times 1000$.

\section{ELECTRON MICROGRAPHS}

Fig. 3. Rhizobium trifolii su297 B without clay. Freeze-dried. Unshadowed; $\times 27,500$.

Fig. 4. $R$. trifolii su297 B without clay. Freeze-dried. Shadowed with gold + palladium; $\times 34,500$.

\section{Plate 2}

Fig. 5. R. trifolii su297 B plus montmorillonite $(80 \mu \mathrm{g} . / \mathrm{ml}$. $)$. Unshadowed; $\times 34,500$.

Fig. 6. $R$. trifolii su297 B plus montmorillonite ( $80 \mu \mathrm{g}$. $/ \mathrm{ml}$.). Shadowed with gold + palladium; $\times 2$ I,000.

Plate 3

Fig. 7. $R$. trifolii su297 B plus illite (100 $\mu \mathrm{g} . / \mathrm{ml}$.). Unshadowed; $\times 34,500$.

Fig. 8. $R$. trifolii su297 B plus illite (100 $\mu \mathrm{g} . / \mathrm{ml}$.). Shadowed with gold + palladium; $\times 43,000$. 
Journal of General Microbiology, Vol. 56, No. 3

Plate I
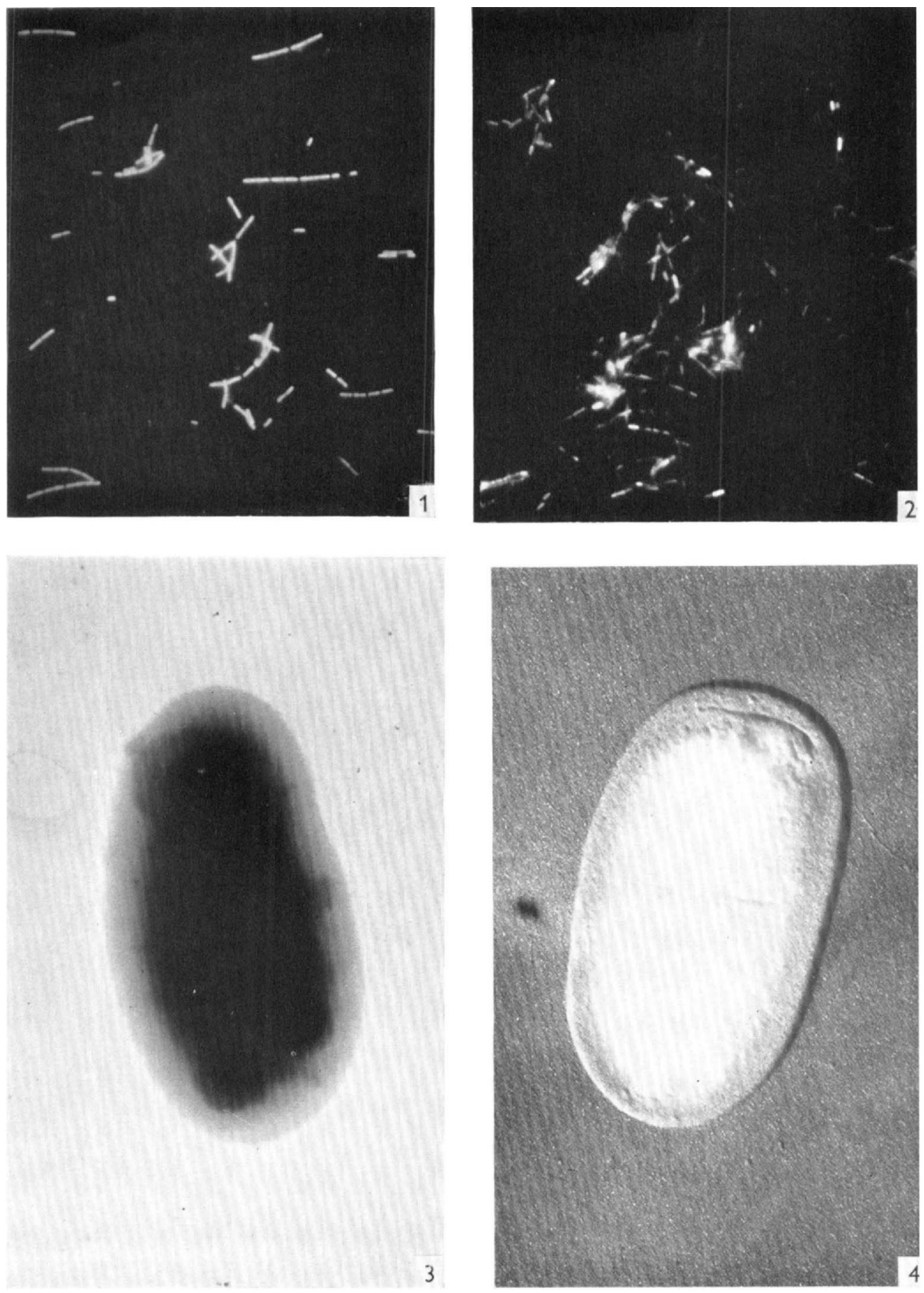

K. C. MARSHALL

(Facing p. 306) 

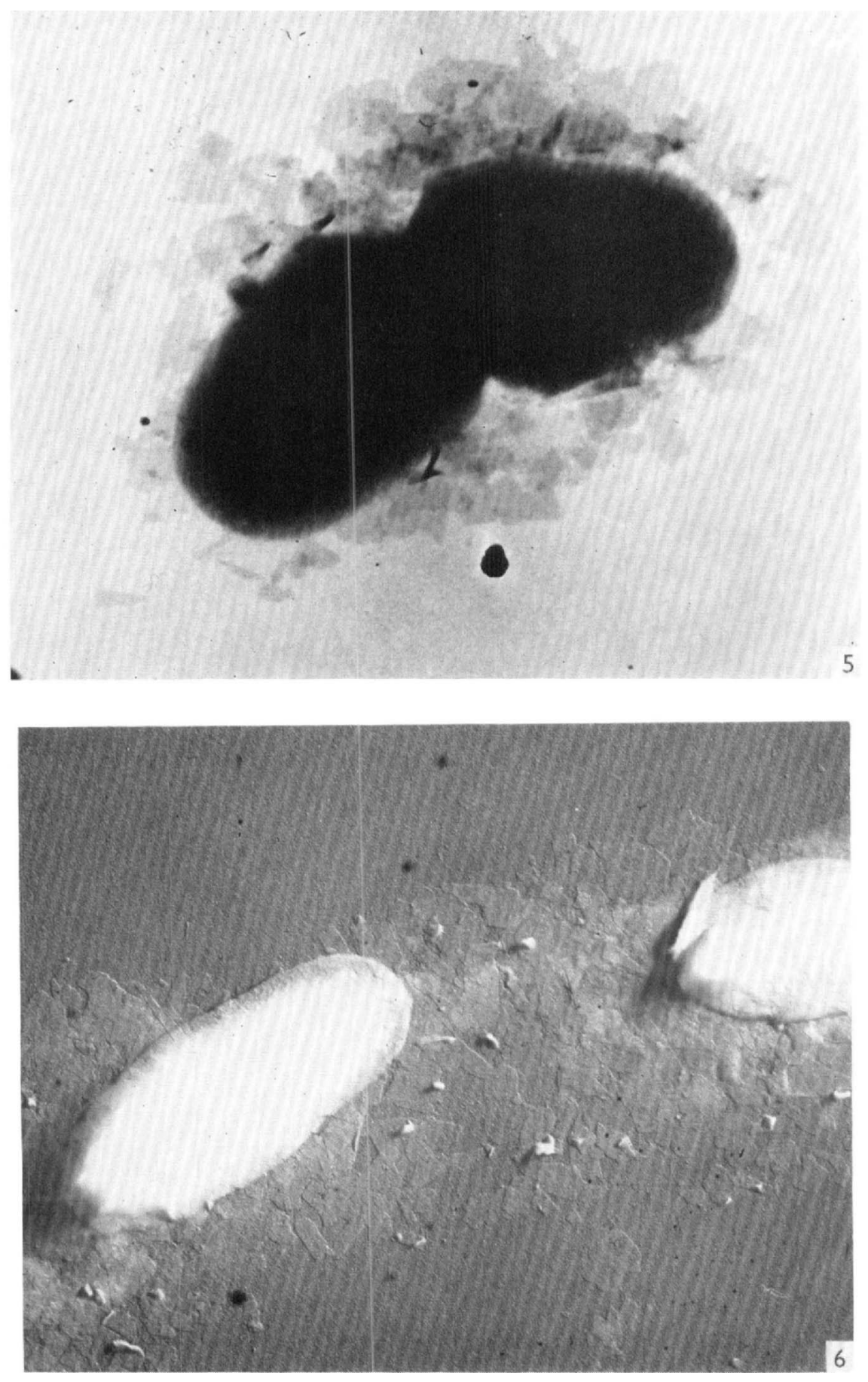

K. C. MARSHALL 

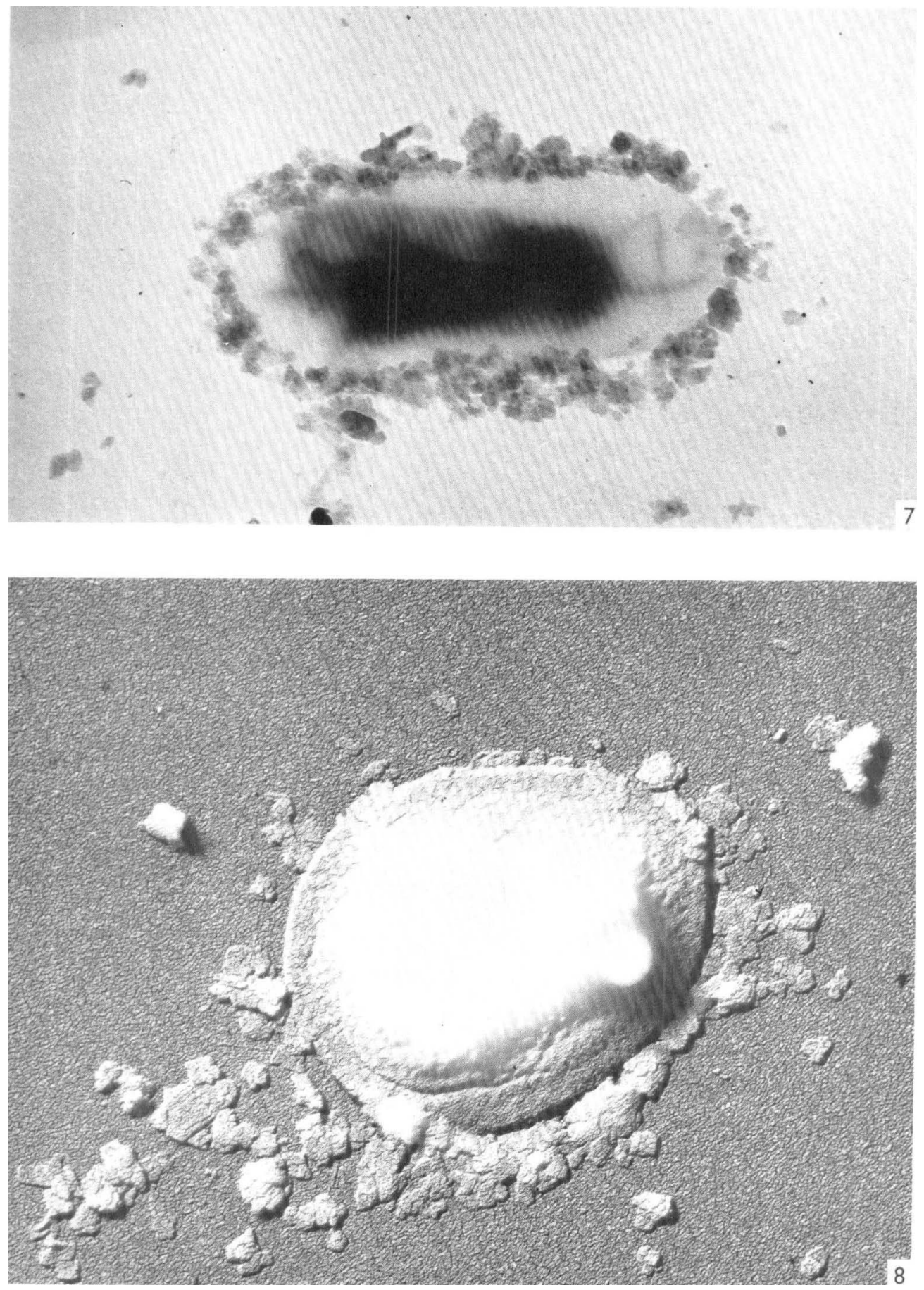

K. C. MARSHALL 